\title{
ABBREVIATIONS OF FREQUENTLY CITED WORKS
}

\begin{tabular}{|c|c|c|c|}
\hline Beckett & & IM & L'instant de ma mort \\
\hline $\mathrm{C}$ & Company & KK & De Kafka à Kafka \\
\hline CSPl & Collected Shorter Plays & LM & The Last Man \\
\hline CSPr & Collected Short Prose & LV & Le livre à venir \\
\hline $\mathrm{D}$ & Disjecta & MD & The Madness of the Day \\
\hline End & Endgame & $\mathrm{PF}$ & La part du feu \\
\hline $\mathrm{HI}$ & How It Is & UV & Une voix venue d'ailleurs \\
\hline $\mathrm{I}$ & L'innommable & WTC & When the Time Comes \\
\hline $\mathrm{MaC}$ & Mercier and Camier & & \\
\hline MD & Malone Dies & Heidegge & \\
\hline $\mathrm{MeC}$ & Mercier et Camier & BT & Being and Time (Stambaugh \\
\hline $\mathrm{MM}$ & Malone Meurt & & translation) \\
\hline MoE & Molloy (English) & KPM & Kant and the Problem of \\
\hline $\mathrm{MoF}$ & Molloy (French) & & Metaphysics \\
\hline $\mathrm{U}$ & The Unnamable & SZ & Sein und Zeit \\
\hline WH & Worstward Ho & & \\
\hline & & Kafka & \\
\hline Blo & & A & Amerika (Max Brod edition) \\
\hline AM & L'arrêt de mort & $\mathrm{BK}$ & Beschreibung eines Kampfes (Max \\
\hline AMV & Au moment voulu & & Brod edition) \\
\hline CQ & Celui qui ne m'accompagnait pas & $\mathrm{BM}$ & Briefe an Milena \\
\hline EI & L'entretien infini & $\mathrm{BON}$ & Blue Octavo Notebooks \\
\hline EL & L'espace littéraire & $\mathrm{Br}$ & Briefe 1902-I924 (Max Brod \\
\hline FJ & La folie du jour & & edition) \\
\hline $\mathrm{IC}$ & Infinite Conversation & CS & Complete Stories \\
\hline
\end{tabular}


D

E Erzäblungen (Max Brod edition)

HL Hochzeitsvorbereitungen auf dem Lande (Max Brod edition)

KA P Der Process (Kritische Ausgabe)

KA TB Tagebücher (Kritische Ausgabe)

LFe Letters to Felice

LFr Letters to Friends, Family, and Editors

LM Letters to Milena

Sons The Sons, ed. Mark Anderson

T The Trial (Breon Mitchell trans.)

TB Tagebücher (Max Brod edition)
Kant

CJ Critique of Judgment (Cambridge edition)

CPrR Critique of Practical Reason

(Cambridge edition)

CPuR Critique of Pure Reason

(Cambridge edition)

Gr Groundlaying of the Metaphysics of Morals (Cambridge edition)

Nancy

GI The Ground of the Image

Note: Quotations from English translations have in many cases been silently modified; citations of English translations are provided for purposes of reference. Where no references are provided, translations are my own. 